[Radiocarbon, Vol. 14, No. 1, 1972, P. 114-139]

\title{
ISOTOPES' RADIOCARBON MEASUREMENTS IX
}

\author{
JAMES BUCKLEY and ERIC H. WILLIS*
}

TELEDYNE ISOTOPES, Westwood, New Jersey

\section{INTRODUCTION}

The measurements presented in this date list were made in the Radiocarbon Dating Laboratory at Teledyne Isotopes during 1969-70. Samples were analyzed by techniques described in R., 1968, v. 10, p. 246. Methods and references to sample pretreatment are provided in $\mathbf{R}$., 1970 , v. 12, p. 87. Errors associated with the age determinations are calculated by combining standard deviations from oxalic acid standard, background, and actual sample data. Samples which approach modern or background are reported with at least $2 \sigma$ limits. Counting time for calculation of errors of background and standard is the same as that used for the sample. The error associated with the De Vries effect and the uncertainty of the half-life are not included.

\section{ACKNOWLEDGMENTS}

We wish to thank our clients who have consented to have their data published in this date list and who have supplied us with the sample descriptions and informative comments. Technical support in the laboratory was supplied by Mr. J. Bonicos. Our thanks are also extended to Mrs. J. Buckley and Mrs. M. Mandel for preparation of the manuscript.

I. GEOLOGIC SAMPLES

\section{A. Western United States}

\section{Thom Watershed series, Tama County, Iowa}

Wood and charcoal fragments from alluvium in side valley of tributary of Four Mile Creek in SE 1/4, Sec. 28, T.86N, R.15W (42 $13^{\prime}$ $\mathrm{N}$ Lat, 92 $34^{\prime} \mathrm{W}$ Long), Tama Co., Iowa. Alluvium overlain by 2.4 m oxidized and leached silt. Coll. 1967 by W. J. Vreeken; subm. by R. V. Ruhe, Water Resources Res. Ctr., Indiana Univ., Bloomington, Indiana.

I-3056. Thom Watershed, 2.4 to $2.6 \mathrm{~m}$

$6200 \pm 125$ 4250 в.c.

I-3057. Thom Watershed, 3.1 to $3.3 \mathrm{~m}$ $7710 \pm 130$

Comment (R.V.R.): dates major valley fill that correlates with beginning of prairie environment (W-235, Rubin and Suess, 1956).

\section{I-3677. Sumner, Bremer County, Iowa}

$23,750 \pm 650$ 21,800 в.c.

Organic carbon and wood fragments from silt interbedded with alluvium next to Little Wapsipinicon R. in SE $1 / 4$ NE 1/4, Sec. 14, T.93N,

* Present address: NMRO, Advanced Research Projects Agency, 1400 Wilson Boulevard, Arlington, Virginia 22209. 
R.11W (42 $51^{\prime} \mathrm{N}$ Lat, $92^{\circ} 05^{\prime} \mathrm{W}$ Long), Bremer Co., Iowa. Sample depth $1.0 \mathrm{~m}$ beneath interbedded clay, sand, and silt (I-1860-1862, R., 1969, v. 11, p. 58). Coll. 1968 by H. J. Kleiss and N. E. Helzer; subm. by R. V. Ruhe. Comment (R.V.R.): dates terrace alluvium on which Sumner Bog formed.

\section{I-3656. Lone Tree, Johnson County, Iowa}

Organic carbon from silt interbedded 22,950 B.c. of Quaternary Lake Calvin in $\left(41^{\circ} 21^{\prime}\right.$ N beneath 3.7 Long), Johnson Co., Iowa. Sample horizon beneath $3.7 \mathrm{~m}$ leached loess and bedded sand (OWU-167, R., 1967, v. 9, p. 319; I-1865, R., 1969, v. 11, p. 58). Coll. 1968 by W. H. Allen and W. J. Vreeken; subm. by R. V. Ruhe. Comment (R.V.R.): date refutes Illinoian age of terrace (Schoewe, 1920).

\section{I-3654. Nichols, Muscatine County, Iowa}

$11,800 \pm 200$

Lake Catin 1 4 , Sec. 9, T.77N, R.4N (41 $28^{\prime} \mathrm{N}$ Lat, $91^{\circ} 20^{\prime}$ W Long), Muscatine Co., Iowa. Sample horizon beneath $3.2 \mathrm{~m}$ loess and alluvium. Coll. 1968 by Jean Prior; subm. by R. V. Ruhe.

\section{I-4409. Hogup Spring, Utah}

$26,700 \pm 900$

Oolitic carbonate from Hogup Spring (3)

W Long), Box Flder Co. Utah Cose 1968 and subm. of Utah. Comment (P.J. J Mehringer, Jr., Dept. Anthropol., Univ. file from Great Salt Lake, Utah.

\section{B. Eastern United States}

\section{I-4910. Mastodon bone, Florida}

$21,150 \pm 400$

Rib bone (Mammut americanum) from $\mathrm{W}$ half Tract 17, Block Plat. 9 of Palm Beach Farms, Sec. 28, T-43-5, R-42-E $\left(26^{\circ} 40^{\prime} 03^{\prime \prime} \mathrm{N}\right.$ Lat, $80^{\circ} 04^{\prime} 05^{\prime \prime} \mathrm{W}$ Long), Palm Beach Co., Florida. Bone level $3 \mathrm{~m}$ depth from area $14 \mathrm{~m}$ by $26 \mathrm{~m}$ (Olsen, 1959). Coll. 1969 and subm. 1970 by H. H. Converse, Jr., Sci. Mus. and Planetarium of Palm Beach Co., Inc. Comment (H.H.C.): most S site in U.S. for major paleontol. excavation. Sample assoc. with bones from various animals including mammoth, bison, horse, camel, tapir sloth, capybara, etc.

\section{I-4163. Guy Wilson Cave, Tennessee}

Bone collagen of extinct peccary (Platygur compressus) 17,750 B.c.

Wilson Cave, S Fork Holston R. (36 $27^{\prime}$. $\mathrm{km}$ SE of Bluff City, Sullivan Co., The $42^{\circ} 13^{\prime} \mathrm{W}$ Long), 4 extinct sink (entirely closed by flowstone), exposed in inner chamber of Guy Wilson Cave. Coll. and subm. 1969 by Carnegie Mus., Sec. of 
Vertebrate Fossils field party. Comment (J.E.G.): meager assoc. fauna includes Synaptomys borealis, Phenacomys, and Citellus tridecemlineatus, indicating cooler climate than at present.

\section{I-2982. Welsh Cave, Kentucky, Peccaries}

$12,950 \pm 550$

11,000 B.c.

Bone collagen (Platygonus compressus) from Welsh Cave (37 $52^{\prime}$ $\mathrm{N}$ Lat, $84^{\circ} 45^{\prime}$ W Long), Woodford Co., Kentucky. Collapsed sink, samples from fill in cave passages (Guilday, 1968b). Coll. 1966 by Carnegie Mus., Sec. of Vertebrate Fossils field party; subm. 1967 by J. E. Guilday. Comment (J.E.G.): assoc. fauna includes mammoth, grizzly bear, badger, 13-lined ground squirrel, many boreal rodents including Microtus xanthognathus, and dire wolf.

\section{Great Marshes series, Massachusetts}

High marsh peat from Great Marshes, $360 \mathrm{~m} \mathrm{E}$ of Navigation Rd., $250 \mathrm{~m} \mathrm{~S}$ of Spring Creek, $60 \mathrm{~m}$ from Upland $\left(41^{\circ} 42^{\prime} 51^{\prime \prime} \mathrm{N}\right.$ Lat, $70^{\circ}$ $21^{\prime} 52^{\prime \prime}$ W Long), W Barnstable, Massachusetts. Peat is $6.1 \mathrm{~m}$ deep, overlies blue clay (I-4648, this list), contains 85 to $90 \%$ water (Kaye and Barghoorn, 1964; Redfield, 1965). Coll. 1969 by A. C. Redfield and K. O. Emery; subm. 1970 by A. C. Redfield, Woods Hole Oceanog. Inst., Woods Hole, Massachusetts.

\section{I-4212. From 1.8 to $2.0 \mathrm{~m}$ depth}

$$
\begin{gathered}
1280 \pm 95 \\
\text { A.D. } 670 \\
1760 \pm 95 \\
\text { A.D. } 190 \\
2100 \pm 100 \\
150 \text { B.c. } \\
2400 \pm 105 \\
450 \text { B.c. } \\
2730 \pm 100 \\
780 \text { B.c. }
\end{gathered}
$$$$
\text { I-4213. From } 2.5 \text { to } 2.7 \mathrm{~m} \text { depth }
$$

I-4214. From 3.4 to $3.5 \mathrm{~m}$ depth

I-4215. From 4.0 to $4.2 \mathrm{~m}$ depth

I-4647. From 4.7 to $4.8 \mathrm{~m}$ depth

General Comment (A.C.R.): to determine degree of compaction of tidalmarsh peat in response to overload, comparisons of age depth relationships between samples from mid-depth in a deep peat layer and those collected immediately over the substratum (Redfield and Rubin, 1962) were made. At depth of $3 \mathrm{~m}$, peat ca. $2100 \mathrm{yr}$ old lies $1 \mathrm{~m}$ below level of formation indicating underlying column was reduced in length by $25 \%$.

\section{I-4648. Barnstable Blue Clay, Massachusetts}

$13,200 \pm 220$

Barnstable blue clay from Great Marshes $\left(41^{\circ} 42^{\prime} 51^{\prime \prime} \mathrm{N}\right.$ Lat, $70^{\circ}$ $21^{\prime} 52^{\prime \prime}$ W Long), W Barnstable, Massachusetts. Core sample depth 6.5 to $6.6 \mathrm{~m}$, clay underlies tidal-marsh peat. Sample composition: water $36.1 \%$, ash $60.4 \%$, organic matter $3.5 \%$ (Woodworth and Wigglesworth, 1934; Prest, 1969). Coll. 1969 and subm. 1970 by A. C. Redfield and 
K. O. Emery. Comment (A.C.R.): clay probably was deposited in meltwater lake between retreating ice front and Sandwich Moraine; date indicates early stage.

\section{Plattville series, Illinois}

Organic carbon assoc. with soil clay $(<2$ micron particle size) from middle terrace above Kankakee R. floodplain, Kankakee Co. $\left(41^{\circ} 12^{\prime}\right.$ $\mathrm{N}$ Lat, $88^{\circ} 01^{\prime} \mathrm{W}$ Long), Illinois. Underlain by nonfractured Niagaran limestone. Coll. and subm. 1968 by T. Ballagh and E. Runge, Univ. of Illinois, Urbana.

\section{I-3770. Plattville 86-95}

$3070 \pm 105$

From B 31 horizon, 86 to $95 \mathrm{~cm}$ depth.

\section{I-3771. Plattville 95-102}

\section{B.C.}

From B 32 horizon, 95 to $102 \mathrm{~cm}$ depth (Bartelli and Odell, 1960).

\section{Wea soil series, Illinois}

Organic carbon complexed with soil clay $(<2$ micron particle size) from high terrace above Kankakee R. floodplain, Kankakee Co. $\left(41^{\circ}\right.$ $12^{\prime} \mathrm{N}$ Lat, $88^{\circ} 01^{\prime} \mathrm{W}$ Long), Illinois. Underlain by coarse limestone. Coll. and subm. 1968 by T. Ballagh and E. Runge.

\section{I-3772. Wea soil, 88-101}

$2935 \pm 105$

From II B 31 horizon, 88 to $101 \mathrm{~cm}$ depth.

985 B.c.

\section{I-3773. Wea soil, 101-110}

From II B 32 horizon, 101 to $110 \mathrm{~cm}$ depth.

550 B.C.

\section{Ashdale soil series, Illinois}

Organic carbon complexed with soil clay ( $<2$ micron particle size) from Stephenson Co. ( $42^{\circ} 22^{\prime} \mathrm{N}$ Lat, $88^{\circ} 35^{\prime} \mathrm{W}$ Long), Illinois. Site underlain by fractured Wise Lake Formation of the Galena dolomite at $116 \mathrm{~cm}$ depth. Coll. and subm. 1968 by T. Ballagh and E. Runge.

\section{I-3971. Ashdale soil, 104-105}

$9330 \pm 190$

From middle of residuum, 84\% clay, II B 31 horizon, 104 to 105 cm depth.

\section{I-3972. Ashdale soil, 115-116}

$4270 \pm 95$

From base of clay-rich zone, II B 32 horizon, 115 to $116 \mathrm{~cm}$ depth. General Comment (E.R.): average organic carbon assoc. with clay increases in age $1000 \mathrm{yr}$ per $15 \mathrm{~cm}$ depth (Sharpenseel, Pietig, and Tamers, 1968). Clay-rich horizons overlying limestone may be product of illuviation of clay from higher horizons and flocculation at the limestone contact by high calcium-ion concentration, resulting in younger age with 
increasing depth. Clay mineralogy, particle-size studies, and carbon dating support this concept (Ballagh and Runge, 1970).

\section{I-4900. Grand Rapids-1, Michigan}

Wood and other plant remains from SE $1 / 4$ NW $1 / 4$, Sec. 34, T.7N, R.12W (43 $57^{\prime} 08^{\prime \prime} \mathrm{N}$ Lat, $85^{\circ} 43^{\prime} 13^{\prime \prime} \mathrm{W}$ Long), Kent Co., Michigan. Sample horizon below 10 to $14 \mathrm{~m}$ sand and till and believed to be stratum below organic zone at John Ball Park (Zumberge and Benninghoff, 1969; Leverett and Taylor, 1915). Coll. 1969 by D. F. Eschman; subm. 1970 by W. R. Farrand, Quaternary Res. Lab., Univ. of Michigan, Ann Arbor, Michigan.

\section{I-5078. GR-3, Grand Rapids}

$33,300 \pm 1800$

Decayed wood fragments from gravel pit in Grand Rapids area, SE $1 / 4$ NW 1/4, Sec. 31, T.8N, R.11W, W of interchange of W River Dr. and U.S. 131, Kent Co. (43 $23^{\prime} \mathrm{N}$ Lat, $85^{\circ} 39^{\prime} 50^{\prime \prime} \mathrm{W}$ Long), Michigan. From near top of thick complex interbedded sand, gravel, and till showing evidence of overriding. Sequence believed stratigraphically younger than John Ball Park organic zone (Zumberge and Benninghoff, 1969). Coll. 1969 by W. Farrand and D. Eschman; subm. 1970 by W. R. Farrand. Comment (W.R.F.): wood somewhat contaminated with modern mold and fungus. Sample may represent part of late Port Talbot complex which is not well known in Michigan. Laboratory Comment: sample very soluble in $\mathrm{NaOH}$ solution; 15 min. treatment resulted in $80 \%$ material loss.

\section{I-5079. GR-4, Grand Rapids}

$28,800 \pm 1050$

26,850 в.c.

Plant remains including Ranunculus, Salix, Dryas integrifolia, and abraded wood fragments from Grand Rapids area SE 1/4 SE 1/4, Sec. 19, T.6N, R.11W, Kent Co. (42 ${ }^{\circ} 53^{\prime} 08^{\prime \prime}$ N Lat, $85^{\circ} 39^{\prime} \mathrm{W}$ Long), Michigan. From many small lenses of organic-rich material in sand at $222 \mathrm{~m}$ surface of Ross Channel (Bretz, 1953). Coll. by R. Rhodes and D. Eschman; subm. 1970 by W. R. Farrand. Comment (W.R.F.): Ross Channel lies between inner and outer Valparaiso morainic ridges and is interpreted as a drainage connection between Glacial Grand R. and Kalamazoo R. at Lake Border time (Eschman and Farrand, 1970). Date unexpected but falls into Farmdalian Interstade widely recognized in Great Lakes area. Thus, organic matter may be reworked from an older deposit.

\section{I-4899. Weaver Drain, Michigan}

$13,770 \pm 210$ 11,820 в.c.

Plant remains, mostly leaves and twigs (Dryas integrifolia, Salix herbacea, Salix sp., and Vaccinium uliginosum) from SE 1/4 SE 1/4, Sec. 15, T.19N, R.12E, Weaver Drain, Lapeer Co. $\left(43^{\circ} 12^{\prime} \mathrm{N}\right.$ Lat, $83^{\circ} 02^{\prime}$ $30^{\prime \prime}$ W Long), Michigan. From unoxidized beds of sand, silt, clay, and organic matter 35.6 to $43.2 \mathrm{~cm}$ above poorly sorted coarse sand overlying unoxidized till in outwash channel. Fossiliferous zone overlain by 
medium to coarse sand (Leverett and Taylor, 1915). Coll. 1969 by W. A. Burgis and subm. 1970 by W. R. Farrand. Comment (W.R.F.): although organic matter is post-till in age, modern ecology and range of species suggest time lag between deposition of till and plant material was short; date represents ice retreat during life of Glacial Lake Maumee III.

\section{Kuhl Mastodon site series, Michigan}

Samples from Lima Township, SW $1 / 4$ NE 1/4, Sec. 33, T.2S, R.4E, Washtenaw Co. (42 $15^{\prime} 24^{\prime \prime}$ N Lat, $85^{\circ} 57^{\prime} 30^{\prime \prime}$ W Long), Michigan, $\mathrm{E}$ edge of depression outside Fort Wayne Moraine. Interbedded peat, shell-rich marls and calcareous, organic sand overlie sample horizons (Russell and Leverett, 1915). Coll. 1969 by R. S. Rhodes; subm. 1970 by W. R. Farrand.

\section{I-5080. KM-5a}

$$
11,050 \pm 160
$$

9100 B.c.

Organic debris washed from calcareous, organic sand, $200 \mathrm{~cm}$ depth, directly below a mastodon vertebra. Comment (W.R.F.): should date earliest organic deposition, establish minimum age for deglaciation outside Fort Wayne Moraine, and maximum age for assoc. mastodon remains. Age agrees well with others of mastodons from Michigan (Wilson, 1967). Other samples being dated by Univ. of Michigan.

\section{I-5081. KM-29a}

$9590 \pm 160$

Wood from peat, $130 \mathrm{~cm}$ depth. Comment (W.R.F.): date is minimum for mastodon remains and is similar to younger ages for mastodons in this area (Skeels, 1962; Wilson, 1967).

\section{I-5082. Saxon, Wisconsin}

Wood (Tsuga canadensis) with 250 growth rings from NW $1 / 4 \mathrm{NE}$ $1 / 4$, Sec. 3, T.46N, R.1W, Iron Co. (46 $36^{\circ} \mathrm{N}$ Lat, $90^{\circ} 29^{\prime} 30^{\prime \prime} \mathrm{W}$ Long), Wisconsin. One of several logs including spruce and tamarack in large sand lens enclosed by red clay till. Elev. ca. $332 \mathrm{~m}$ which approximates upper limit of Glacial Lake Duluth in this area (Leverett, 1929). Coll. 1968 by G. E. Lindsay; subm. 1970 by W. R. Farrand. Comment (W.R.F.): site seems assoc. with last ice advance before Glacial Lake Duluth. But date is too young to fit usual late-glacial history (Farrand, 1969; Black, 1969). Spruce wood from this site was dated at 10,100 \pm 100 B.P. (WIS-409, unpub.). These dates fall into a group (Black, 1969) and are considered anomalous at present. They are 1000 to 2000 $\mathrm{yr}$ too young, implying much later glaciation on $\mathrm{S}$ shore of Lake Superior than generally admitted.

\section{Fiano Romano series, Italy}

\section{Europe}

Wood from $3 \mathrm{~m}$ depth in alluvial fill, maximum thickness $8.50 \mathrm{~m}$, right bank Tiber R. (42。 $11^{\prime} 55^{\prime \prime} \mathrm{N}$ Lat, $12^{\circ} 36^{\prime} 27^{\prime \prime} \mathrm{E}$ Long), near Fiano Romano, Italy. Coll. 1969 and subm. 1970 by C. Vita-Finzi. 
I-4801. Fiano 2

\section{I-4802. Fiano 1}

General Comment (C.V-F.): dates support contention (Vita-Finzi, 1966) that youngest fill in Tiber valley corresponds with historic deposit of Mediterranean valleys (Vita-Finzi, 1969). Similar deposit was reported from S. Etruria by Judson (1963).

\section{I-4963. Shortalstown Td., Ireland}

$12,160 \pm 180$ 10,210 в.c.

Brown, laminated, late-glacial mud from kettle $8 \mathrm{~km} \mathrm{S-SW}$ of Wexford town, Shortalstown Td. $\left(52^{\circ} 16^{\prime} \mathrm{N}\right.$ Lat, $06^{\circ} 30^{\prime} \mathrm{W}$ Long), Ireland. Coll. 1968 and subm. 1970 by G. F. Mitchell, Univ. of Dublin, Ireland. Comment (G.F.M.): one of a late-glacial series of deposits resting in kettle; it contained remains of Cervus giganteus, the Giant Irish deer; date agrees well with other similar deposits (Colhoun and Mitchell, ms. in preparation).

\section{I-4730. Corrie Brochain, Cairngorm Mountains, $1905 \pm 95$ Scotland}

Peat from floor of cirque basin in central Cairngorm Mts. $\left(57^{\circ} 06^{\prime}\right.$ $\mathrm{N}$ Lat, $03^{\circ} 40^{\prime} \mathrm{W}$ Long), Scotland. From peat overlain by gravel, alt ca. 1000 m. Coll. and subm. 1969 by D. E. Sugden, Dept. Geog., Univ. of Aberdeen, Scotland. Comment (D.E.S.): building of cirque moraines antedates formation of peat; hence cirque does not date 17th to 19th centuries little ice age.

\section{I-5070. W Newbie Cottage, Dumfriesshire}

$4290 \pm 100$ 2340 B.c.

Peat from near top of low cliff $\mathrm{N}$ shore Solway Firth, $290 \mathrm{~m} \mathrm{~W}$ of Newbie Cottages, Nat. Grid Ref. NY 167649 (54 $4^{\circ} 58^{\prime}$ N Lat, 03 $18^{\prime}$ W Long), Dumfriesshire, Scotland. From basal $7 \mathrm{~cm}$ of $40 \mathrm{~cm}$ thick peat, overlying Carse Deposits of Flandrian marine transgression. Coll. 1966 and subm. 1970 by W. G. Jardine. Comment (W.G.J.): dates local commencement of peat growth, and minimum age for end of Flandrian marine transgression along $\mathrm{N}$ shore of Solway Firth (Godwin and Willis, 1962; Godwin et al., 1965).

\section{Lake Elmenteita series, Kenya}

$$
\text { D. Africa }
$$

Gyttja core samples from Lake Elmenteita $\left(0^{\circ} 25^{\prime} \mathrm{S}\right.$ Lat, $36^{\circ} \quad 15^{\prime}$ E Long), E Rift Valley, Kenya. Coll. 1969 and subm. 1970 by A. E. Richardson and J. L. Richardson, Dept. Biol., Franklin and Marshall College, Lancaster, Pennsylvania (Washbourn, 1967; Washbourn and Kamar, 1970).

\section{I-5177. Lake Elmenteita, 2038 to $2081 \quad 27,370$ B.c. \\ 2038 to $2081 \mathrm{~cm}$ below mud-water interface, water depth $187 \mathrm{~cm}$.}


Comment (J.L.R.): lowest organic sediments obtained, underlying several $\mathrm{m}$ volcanic ash and pumice. Microfossils suggest small, fresh lake rapidly developing into alkaline lake.

\section{I-5178. Lake Elmenteita, 974 to 1020.5}

$12,200 \pm 180$ 10,250 в.c.

974 to $1020.5 \mathrm{~cm}$ below mud-water interface. Comment (J.L.R.): level lies just below $\mathrm{S}$ band of volcanic ash, alkaline water conditions indicated.

\section{I-5179. Lake Elmenteita, 636 to 672}

$8740 \pm 190$

636 to $672 \mathrm{~cm}$ below mud-water interface. Comment (J.L.R.): level indicates highest and freshest phase of now-alkaline lake in last 29,000 yr.

\section{E. Australia}

\section{Lake Gnotuk series, Victoria}

Necron mud, composed entirely of decayed plankton, from Lake Gnotuk (38 $18^{\circ} \mathrm{S}$ Lat, $143^{\circ} 06^{\prime}$ E Long), Camperdown, Victoria. Coll. 1967 and subm. 1969 by D. M. Churchill, Monash Univ., Victoria, Australia.

\section{I-3977. Sample 1, 0 to $7 \mathrm{~cm}$}

$625 \pm 95$

From topmost $7 \mathrm{~cm}$ of organic peat overlying ash in Lake Gnotuk at water depth $20 \mathrm{~m}$. Comment (D.M.C.): $\mathrm{C}^{13} / \mathrm{C}^{12}$ ratio is -23.2 relative to PDB standard, indicating carbon is from normal autotrophic plants with no fractionation. True age of sample $<15 \mathrm{yr}$, as pollen below this level marks introduction of European plants into area. Close examination revealed some old necron mud eroded from crater walls incorporated into sample.

\section{I-4101. Sample 2, Core 2}

$$
\begin{aligned}
& 9030 \pm 145 \\
& 7080 \text { в.с. }
\end{aligned}
$$

From contact of organic necron mud with underlying inorganic volcanic ash, 310 to $340 \mathrm{~cm}$ depth from surface of mud. Comment (D.M.C.): date indicates age of last volcanic eruption in Camperdown area.

\section{I-4102. Sample 3, Core 2}

From freshwater phase of lake's history, 210 to $230 \mathrm{~cm}$ depth. Comment (D.M.C.): dates change of volcanic crater lake water from highly saline to fresh. Water became resalinified and is presently 55\%o saline.

\section{I-4103. Lake Bullenmerri, Victoria}

$3610 \pm 90$

Necron mud, composed entirely of decayed plankton, from Lake Bullenmerri ( $38^{\circ} 14^{\prime} \mathrm{S}$ Lat, $143^{\circ} 06^{\prime} \mathrm{E}$ Long), Camperdown, Victoria Sample 1, Core 1, 210 to $230 \mathrm{~cm}$ depth in lake mud, $61 \mathrm{~m}$ below water surface. Coll. 1967 and subm. 1969 by D. M. Churchill. Comment 
(D.M.C.): date indicates much younger fresh-water phase than adjacent Lake Gnotuk (I-4102, this list). From evidence of fossil phytoplankton, this freshwater phase was preceded and succeeded by long phase of brackish water conditions. Present salinity of lake is $8 \%$.

\section{I-4104. Cobrico Swamp, Victoria}

$7580 \pm 135$ 5630 B.c.

Calcareous necron mud from Cobrico Swamp $\left(38^{\circ} 18^{\prime} \mathrm{S}\right.$ Lat, $143^{\circ}$ 02' E Long), Camperdown, Victoria. Sample 1, 350 to $400 \mathrm{~cm}$ depth, from level characterized by onset of open water conditions and marked increase in organic matter, expressed on dry weight basis. Coll. 1966 and subm. 1969 by D. M. Churchill. Comment (D.M.C.): dates onset of normal lake succession.

\section{F. Canada}

\section{Lake Joncas series, Canada}

Peat and silty clay from bog of Lake Joncas outlet, Forêt Expérimentale Montmorency de l'Univ. Laval, Quebec, ca. $80.5 \mathrm{~km} \mathrm{~N}$ of Quebec City, Map no. 21M/6E $\left(47^{\circ} 15^{\prime} 30^{\prime \prime} \mathrm{N}\right.$ Lat, $71^{\circ} 09^{\prime} 45^{\prime \prime} \mathrm{W}$ Long), Canada.

\section{I-4756. JON 1}

$4710 \pm 170$

Holocene peat. Coll. 1969 and subm. 1970 by Pierre Richard, Lab. Palynol. Fac. Sci., Montpellier, France. Comment (P.R.): date refers to pine pollen maximum for region. Interpretation of pollen diagram implies balsam fir forest as regional vegetation.

\section{I-5083. JON 2}

$7140 \pm 130$ 5190 B.c.

Peat and silty clay from limit between Late and postglacial for region, beginning of organogenic sediments. Coll. and subm. 1970 by M. Grandtner. Comment (P.R.): date refers to limit between tundra and open forests of $\mathrm{N}$ birches and black spruce. These phytogeographic units were very typically identified by pollen analysis and lead to new interpretation for vegetational history in region.

\section{ARCHAEOLOGIC SAMPLES \\ A. Western United States}

\section{I-4782. Menlo Baths site, LMA1-191451}

Mammal bones from Menlo Baths site, lower Surprise Valley, Modoc Co., (41 ${ }^{\circ} 16^{\prime} \mathrm{N}$ Lat, $120^{\circ} 05^{\prime} \mathrm{W}$ Long), California. From occupation surface $117 \mathrm{~cm}$ below surface, assoc. with large side-notched projectile points (Gruhn, 1961). Coll. 1967 by J. F. O'Connell and C. R. Corson; subm. 1970 by J. F. O'Connell, Dept. Anthropol., Univ. of California, Berkeley. Comment (J.F. O'C): date consistent with time of similar material from Columbia Plateau (Warren, 1968). Date on another portion of sample was $13,750 \pm 250$; rejected as inconsistent. 
I-4528. Buchanan Archaeol. Project, Sample 3

$1265 \pm 95$

Charcoal from Buchanan Reservoir locality of Chowchilla R. (37 $13^{\prime}$ 25" N Lat, $119^{\circ}$ 59' 02" W Long), Madera Co., California. Site CA-Mad-107, Unit G-96, depth 100 to $110 \mathrm{~cm}$ below surface. From large ash lens assoc. with several projectile points. Coll. and subm. 1969 by M. J. Moratto, San Francisco State College, California. Comment (M.J.M.): dates terminal portion of lower component occupation in Buchanan Reservoir region and initial part of upper component.

\section{I-4798. Golden Gate National Cemetery, SMa-100}

$1060 \pm 95$

Charcoal from $.4 \mathrm{~km}$ E of Golden Gate Natl. Cemetery near Sneath Lane and Hwy. 280, San Mateo Co. ( $37^{\circ} 37^{\prime} \mathrm{N}$ Lat, $122^{\circ} 25^{\prime} \mathrm{W}$ Long), California. From rim of house floor $55 \mathrm{~cm}$ below surface, assoc. with artifacts of Phase I, Late horizon (Van Dyke, 1969). Coll. 1969 and subm. 1970 by S. Van Dyke and R. Schenk, San Francisco State College, California. Comment (S.V.D.): date indicates middle part of Phase I, Late horizon.

\section{Lovelock Cave series, Nevada}

Organic material from Lovelock Cave, SE 1/4 SW 1/4 NE $1 / 4$, Sec. 12, T.24N, R.30E (39 $57^{\prime} 42^{\prime \prime} \mathrm{N}$ Lat, $118^{\circ} 33^{\prime} 24^{\prime \prime} \mathrm{W}$ Long), Nevada. Coll. and subm. 1968 by R. F. Heizer and L. K. Napton, Dept. Anthropol., Univ. of California, Berkeley.

\section{I-3962. AN-16}

$4690 \pm 110$

Bat guano and tule rushes from occupation layer $200 \mathrm{~cm}$ below datum plane, Test Unit AN (Loud and Harrington, 1929; Grosscup, 1960).

\section{I-3963. LX-10}

$1470 \pm 90$

Coprolite from $143 \mathrm{~cm}$ below datum plane, Test Unit LX (Napton, 1969).

\section{B. Eastern United States}

\section{Caxambus Point, Marco Island series, Florida}

Charcoal from Caxambus Point, Marco I. (25 $54^{\prime} 56^{\prime \prime} \mathrm{N}$ Lat, $81^{\circ} 42^{\prime}$ 55" W Long), Collier Co., Florida. Coll. 1968 and subm. 1969 by L. R. Morrell, Florida Bur. Hist. Sites and Properties, Dept. of State, Tallahassee, Florida.

\section{I-4568. Caxambus 1}

$1995 \pm 160$ 45 B.c.

8 Cr $107 \times 1$ Test 2, Sq. 100, Level $3,0.40$ to $0.60 \mathrm{~m}$ below surface. Contained mostly fiber-tempered Orange Incised and Plain ceramics with some sand-tempered plain. Comment (L.R.M.): sample considered intrusive from a surface Glades I occupation. 
I-4569. Caxambus 2

8 Cr $107 \times 1$ Test 2, Sq. 100, Level 4, 0.60 to $0.80 \mathrm{~m}$ below surface. Mostly fiber-tempered Orange Incised and Plain ceramics with minor sand-tempered plain. Comment (L.R.M.): this and Level 7 date (I-4570, this list) suggest a later occupation for Test 2 area than Test 3 area, but still represent late Orange decorated period.

\section{I-4570. Caxambus 3}

$3060 \pm 105$

8 Cr. $107 \times 1$ Test 2 , Sq. 100 , Level $7,1.20$ to $1.40 \mathrm{~m}$. Level 7 contained little cultural material attributable to an intrusion from Levels 4 and 5. Comment (L.R.M.): Test 2 and 3 areas were small midden deposits, suggesting single family residence. The ca. $200 \mathrm{yr}$ separation of Test 2 and 3 dates suggests a later holdover of late Orange ceramics than previously considered.

\section{I-4571. Caxambus 4}

$3375 \pm 105$ 1425 B.c.

8 Cr $107 \times 1$ Test 3, Sq. 109, Level 2, 0.20 to $0.40 \mathrm{~m}$. Mostly fibertempered Orange Incised and Plain ceramics with minor sand-tempered plain. Comment (L.R.M.): this date with I-4572 and I-4573 (this list) represent a single occupation. Caxambus site extends known area of Orange influence $241 \mathrm{~km} \mathrm{~S}$.

\section{I-4572. Caxambus 5}

$3315 \pm 105$

8 Cr $107 \times 1$ Test 3 , Sq. 109 , Level $3,0.40$ to $0.60 \mathrm{~m}$.

\section{I-4573. Caxambus 6}

$3400 \pm 100$

1450 B.C.

$8 \mathrm{Cr} 107 \times 1$ Test 3, Sq. 109, Level 4, 0.60 to $0.80 \mathrm{~m}$. Deepest level for sand-tempered ceramics.

\section{Monocacy site series, Maryland}

Charcoal from Monacacy site on point at junction $W$ bank of Monocacy and $\mathrm{N}$ bank of Potomac Rivers, site 18 FR 100, approx. middle of Potomac Piedmont (39 $19^{\circ} 13^{\prime} 28^{\prime \prime}$ N Lat, $77^{\circ} 27^{\prime} 14^{\prime \prime}$ W Long), Frederick Co., Maryland. Coll. 1969 and subm. 1970 by W. M. Gardner and C. W. McNett, Jr., Dept. Anthropol., Catholic Univ., Washington, D.C.

\section{I-5088. Monocacy 1}

$285 \pm 90$

\section{A.D. 1665}

From top of 1 st of 3 prehistoric levels separated by sterile strata. Assoc. pottery is heavily quartz-tempered, some shell- and limestonetempered from Late Woodland occupation.

I-5089. Monocacy 2

$715 \pm 90$

From base of 1st cultural level. Assoc. pottery is Late Woodland, mostly quartz-tempered. 
I-5090. Monocacy 3

From top of 2nd cultural level, with transition of steatite-tempered to fine sand-tempered cordmarked pottery, Early Woodland.

\section{I-5091. Monocacy 4}

$$
2900 \pm 95
$$

950 B.c.

From base of 2nd cultural level. Comment (W.M.G.): dates directly assoc. with heavily-tempered, plain steatite-tempered pottery, 1st pottery in Potomac valley. Cultural assoc.: Early Woodland.

\section{Macauley complex series, New York}

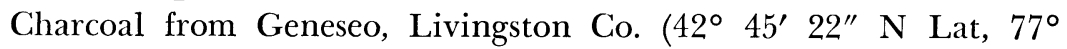
$50^{\prime} 20^{\prime \prime} \mathrm{W}$ Long), New York. From Site 4 on postglacial river terrace uncomformably overlying proglacial lake varves and till. Thin persistent oxidized zones, sedimentary structures and undisturbed features assoc. with artifacts. Coll. and subm. 1969 by W. J. Wells and W. D. Rhodes, Dept. Anthropol., State Univ. New York, Geneseo.

\section{I-4267. Macauley I}

$3670 \pm 110$

Firepit from Test Block 1, $114 \mathrm{~cm}$ depth. First glacial varve at 153 cm.

\section{I-4364. Macauley II}

$3300 \pm 105$

Storage pit from Loc. $3,38 \mathrm{~cm}$ depth. Pit starts at $23 \mathrm{~cm}$ depth; contained charred bones and acorns.

\section{I-4515. Macauley III}

$2890 \pm 200$

940 в.c.

Hearth from Loc. 2, $46 \mathrm{~cm}$ depth. Hearth contained flint chips, bone, and projectile point; extended to $59 \mathrm{~cm}$ depth.

\section{I-4558. Macauley IV}

$2670 \pm 115$

From burnt area between 1st and 2nd oxide layers, $25 \mathrm{~cm}$ depth, Test Block 2, Loc. 2. Assoc. with 3 adzes of varying form.

\section{Susquehanna series, New York}

Charcoal from A(dequentaga) site $\left(42^{\circ} 26^{\prime} 45^{\prime \prime} \mathrm{N}\right.$ Lat, $75^{\circ} 01^{\prime} 15^{\prime \prime}$ W Long), New York. Subm. 1970 by B. E. Raemsch, Dept. Anthropol., Hartwick Coll., Oneonta, N.Y.

\section{I-4455. A(dequentaga) 90-a}

$4090 \pm 125$

From old erosional surface on glacial till, overlain by river gravel, $230 \mathrm{~cm}$ below surface. Coll. 1969 by B. Raemsch and A. Moyer. Comment (B.E.R.): sample was attempt to date large percussion-flaked tool industry; represents intrusion or was washed into position from a higher terrace. 
I-4444. A(dequentaga) 90-b

Duplicate of I-4455.

I-4446. A(dequentaga) 31

2030 B.c.

Taken at $79 \mathrm{~cm}$ depth. Charcoal intruded into river gravel to 135 $\mathrm{cm}$ depth, from hearth containing Susquehanna cultural artifacts. Coll. 1969 by D. Roper. Comment (B.E.R.): date agrees with another from Susquehanna culture (I-3974, R., 1970, v. 12, p. 120) but both are somewhat earlier than Ritchie's for same culture.

I-4367. A(dequentaga) 23-26

$1630 \pm 95$

From hearth 59 to $66 \mathrm{~cm}$ below surface, assoc. with artifacts of Steubenville culture. Agrees with similar sample (I-3731, R., 1970, v. 12 , p. 120) and correlates black line horizon-1 with occupation throughout Steubenville site (Raemsch, 1970). Coll. 1970 by B. E. Raemsch.

I-4557. A(dequentaga) 15

$1345 \pm 95$

From $38 \mathrm{~cm}$ depth between Steubenville and Iroquois horizons. Coll. 1969 by D. Laist. Comment (B.E.R.): dates occupation by Jack's Reef people; agrees with point typology and pottery.

I-4445. A(dequentaga) 15-a

$1080 \pm 95$

From ca. $38 \mathrm{~cm}$ below surface between Steubenville and Iroquois horizons. Coll. 1969 by D. Roper and J. Biesemeyer.

I-4378. A(dequentaga) 12

A.D. 1480

$470 \pm 90$

From large hearth 31 to $48 \mathrm{~cm}$ depth just below plow line. Iroquois rim sherd and triangular Madison-type points assoc. with sample. Coll. 1969 by J. Biesemeyer and B. Raemsch.

I-4366. A(dequentaga) 10

$330 \pm 90$

From hearth 25 to $41 \mathrm{~cm}$ depth. Type Iroquois pottery; Madison points and $\operatorname{dog}$ bones assoc. Coll. 1969 by B. Raemsch.

\section{Coffin site series, New York}

Charcoal from Coffin site, Washington Co. $\left(43^{\circ} 05^{\prime} 47^{\prime \prime} \mathrm{N}\right.$ Lat, $73^{\circ} 34^{\prime}$ 24" W Long), New York. Coll. 1969 and subm. 1970 by R. E. Funk, New York State Mus. and Sci. Service, Albany, N.Y.

\section{I-4835. Coffin W50N10}

From a hearth, Feature 4, upper portion of St. 4, Sec. W50N10. Assoc. with Orient Fishtail points and a soapstone sherd. Comment (R.E.F.): date agrees with estimate for artifact assemblage; shows close affiliation with Orient culture of Long Island (Ritchie, 1965). 
I-4836. Coffin W5NO

From general midden in upper portion of St. 4, Sec. W5N0.

\section{I-4837. Ten Mile River Rock Shelter, New York \\ $4450 \pm 130$ \\ 2500 B.C.}

Bone from Ten Mile R. Rock Shelter, Tusten Township, Sullivan Co. ( $41^{\circ} 33^{\prime} \mathrm{N}$ Lat, $75^{\circ} 01^{\prime} \mathrm{W}$ Long), New York. From black midden of lowest occupation zone, Sec. EON20. Assoc. side-notched, cornernotched, and triangular points appear to represent Vosburg Laurentian component (Funk, ms. in preparation). Coll. 1969 and subm. 1970 by R. E. Funk. Comment (R.E.F.): date consistent for Vosburg complex in $\mathrm{E}$ New York and Connecticut.

\section{I-4838. Davenport Creamery site, New York}

$1625 \pm 95$

Charcoal from Davenport Creamery site, Delaware Co. $\left(42^{\circ} 26^{\prime}\right.$ $44^{\prime \prime} \mathrm{N}$ Lat, $74^{\circ} 55^{\prime} 30^{\prime \prime}$ W Long), New York. From Feature 1, Sec. E5N25 in upper occupation zone, assoc. with thin side-notched points and rocker-stamped pottery. Coll. 1969 and subm. 1970 by R. E. Funk. Comment (R.E.F.): date close to early Middle Woodland manifestation.

\section{I-4137. Dutchess Quarry Cave, New York}

$12,530 \pm 270$

Bone collagen of Woodland Caribou (Rangifer tarandus) from Florida (41 $21^{\prime} 42^{\prime \prime} \mathrm{N}$ Lat, $74^{\circ} 21^{\prime} 48^{\prime \prime} \mathrm{W}$ Long), Orange Co., New York. From St. 2, with a fluted point and a few intrusive bones of elk and deer (Funk et al., 1970; 1969a; 1969b; Guilday, 1968a, 1969). Coll. 1965 by members of Orange Co. Chap. N.Y.S. Archeol. Assoc., subm. 1968 by E. M. Reilly, Jr., N.Y.S. Mus. and Sci. Service. Comment (E.M.R.): date confirms late Wisconsin age of caribou bones probably brought to cave by man. They occur in same level as fluted point and presumably pertain to Paleo-Indian occupation of cave. But date indicates greater age for fluted point tradition than generally accepted by archaeologists.

I-5236. Frontenac Island site, Cat. AP648

$3850 \pm 95$ 1900 B.C.

Human bone collagen from Frontenac I. $\left(42^{\circ} 50^{\prime} 30^{\prime \prime} \mathrm{N}\right.$ Lat, $76^{\circ}$ $42^{\prime} 30^{\prime \prime} \mathrm{W}$ Long), Cayuga Co., New York. From burial 78 of young adult male with rich assortment of grave goods pertaining to Archaic Frontenac phase (Ritchie, 1945; 1965). Coll. 1939; subm. 1970 by W. A. Ritchie, N.Y.S. Mus. and Sci. Service. Comment (W.A.R.): date agrees with 2 charcoal dates from separate hearth features of same level (3970 \pm 80 в.P., Y-459, R., v. 1, 1959, p. 161 and $3680 \pm 250$ в.P., W-545, R., v. 2, 1960, p. 180).

\section{Parker site series, Pennsylvania}

Charcoal from Parker site, $36 \mathrm{Lu} 14\left(41^{\circ} 17^{\prime} \mathrm{N}\right.$ Lat, $75^{\circ} 51^{\prime} 42^{\prime \prime}$ W Long), Luzerne Co., Pennsylvania. Coll. 1968 and subm. 1970 by 
I. F. Smith III, William Penn Mem. Mus., Harrisburg, Pennsylvania (Smith, 1968).

I-4879. Feature 45 a

From Sq. N40E70, Feature 45 a. Feature is part of or intrusive into nearby semi-subterranean living structure. Comment (I.F.S.): Parker site is prehistoric, date is too recent.

I-4880. Feature 45

A.D. 1470

$480 \pm 90$

From Sq. N40E60, Feature 45. Semi-subterranean living structure with burned grasses covering floor and burned logs or saplings collapsed onto grass. Artifacts include: Susquehannock and Proto-Mohawk-like pottery, cobble choppers, chipped stone, hammerstones, grinding slab. Comment (I.F.S.): date agrees with estimated age of village.

I-4881. Feature 54

$350 \pm 90$

From Sq. N30E50, Feature 54, a semi-subterranean living structure. Artifacts found in stone hearth within structure: Proto-Mohawk-like pottery, net sinker, and carbonized cultigens.

\section{Canada}

\section{Rose Island series, N Labrador}

Wood charcoal from W shore Rose I., Saglek Bay, N Labrador. Subm. 1970 by J. A. Tuck, Dept. Sociol. and Anthropol., Mem. Univ. of Newfoundland, Canada.

\section{I-5249. Site $Q$, Feature 10}

$4530 \pm 105$

From large stone hearth in Band 7A (58 31' $51^{\prime \prime} \mathrm{N}$ Lat, $62^{\circ} 58^{\prime}$ 27" W Long), Site Q, Feature 10. Coll. by J. A. Tuck. Comment (J.A.T.): dates earliest occupation discovered at Saglek Bay. Assoc. large crude "stemmed flake" tools, fragments of ground slate points and inferred sea mammal hunting economy, suggest Maritime Archaic affiliations (Tuck, ms. in preparation).

\section{I-5251. Site Q, Feature 13}

$3890 \pm 110$

1940 B.c.

From stone hearth in Band 4A $\left(58^{\circ} 31^{\prime} 51^{\prime \prime} \mathrm{N}\right.$ Lat, $62^{\circ} 58^{\prime} 27^{\prime \prime}$ W Long), Site Q, Feature 13. Coll. by D. O. Bowden, III. Comment (J.A.T.): dates terminal Maritime Archaic occupation at this station. Proximity of time to overlying Archaic Small Tool tradition (1880 B.C., I-5250, this list) suggests contact between the 2 cultures.

\section{I-5250. Site Q, Feature 2}

$3830 \pm 115$

From stone hearth in Band $4\left(58^{\circ} 31^{\prime} 51^{\prime \prime} \mathrm{N}\right.$ Lat, 62 $58^{\prime} 27^{\prime \prime} \mathrm{W}$ Long), Site Q, Feature 2. Coll. by J. A. Tuck. Comment (J.A.T.): dates earliest pre-Dorset Arctic Small Tool tradition occupation at Site Q. 


\section{I-5252. Site E, Stratum 2}

$2715 \pm 130$

765 B.c.

From concentration of charcoal in Stratum $2\left(58^{\circ} 30^{\prime} 58^{\prime \prime} \mathrm{N}\right.$ Lat, $62^{\circ} 57^{\prime} 25^{\prime \prime} \mathrm{W}$ Long), Site E. Coll. by J. A. Tuck. Comment (J.A.T.): date is probably slightly late but not unreasonable for late pre-Dorset assemblage.

\section{I-5253. Site W, Loc. III}

Scattered charcoal from cultural layer $8 \mathrm{~cm}$ to $13 \mathrm{~cm}$ deep $\left(58^{\circ}\right.$ $31^{\prime} 12^{\prime \prime} \mathrm{N}$ Lat, $62^{\circ} 58^{\prime} 50^{\prime \prime} \mathrm{W}$ Long), Site W, Loc. III. Coll. by D. O. Bowden, III. Comment (J.A.T.): date acceptable for terminal Dorset Eskimo occupation.

\section{I-5254. Ikkusik site, House 21}

$$
275 \pm 90
$$

Preserved wood from floor of House $21\left(58^{\circ} 30^{\prime} \mathrm{N}\right.$ Lat, $62^{\circ} 58^{\prime}$ W Long), a prehistoric Thule Eskimo sod house, Ikkusik site. Coll. by P. Schledermann. Comment (J.A.T.): date corrected to ca. A.D. 1520 by Suess curve is close to supposed date of 1st Thule Eskimo penetration of Labrador coast.

\section{I-4375. Observation site (KeNw-4), Great Slave Lake, Canada}

Charcoal from promontory at mouth of Mackinlay R., McLeod Bay, Great Slave Lake (62 $42^{\prime} 35^{\prime \prime} \mathrm{N}$ Lat, $111^{\circ} 24^{\prime} 48^{\prime \prime}$ W Long), Canada. From hearth $13 \mathrm{~cm}$ deep, assoc. with small side-notched points alongside silicious shale lanceolates, bifaces, wedges, and ground stone. Coll. 1968 and subm. 1969 by W. C. Noble, McMaster Univ., Hamilton, Ontario. Comment (W.C.N): site represents late prehistoric component of Taltheilei Shale tradition which terminated with Yellowknife Indians.

\section{I-4376. Deception Point (L6Pf-5), Snare Lake, $\quad 5070 \pm 140$ Canada

Charcoal from N shore Snare Lake, N.W.T. $\left(64^{\circ} 14^{\prime} 20^{\prime \prime}\right.$ N Lat, $113^{\circ} 56^{\prime} 50^{\prime \prime} \mathrm{W}$ Long), Canada. Lens $3 \mathrm{~cm}$ thick from depth $46 \mathrm{~cm}$, overlying podsol on fine white esker sand. Above are 2 zones of aeolian sand 15 to $25 \mathrm{~cm}$ thick separated by 5 to $8 \mathrm{~cm}$ cultural layer. Coll. 1967 and subm. 1969 by W. C. Noble. Comment (W.C.N.): date and burned soil horizon represents earliest evidence for forest burning in tundrataiga region of central dist. of MacKenzie, N.W.T.

\section{I-4550. Hennessey site (KfNm-3), Canada}

$$
540 \pm 95
$$

Charred caribou bone from $13 \mathrm{~cm}$ depth in circular pit structure at extreme $\mathrm{S}$ end Hennessey site, E shore Artillery Lake directly opposite narrows at Timber Bay (62 $55^{\prime} 55^{\prime \prime} \mathrm{N}$ Lat, $108^{\circ} 13^{\prime} \mathrm{W}$ Long), Canada. Site $11 \mathrm{~m}$ above present lake level on tundra-covered terrace. Coll. and subm. 1969 by W. C. Noble. Comment (W.C.N.): does not date main 
archaeol. complex represented at Hennessey, but late Frank Channel phase.

\section{I-4972. Porteous site, Canada}

$1125 \pm 100$

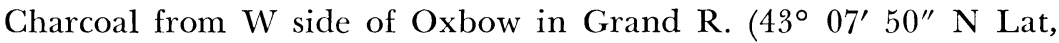
$80^{\circ} 13^{\prime} 30^{\prime \prime} \mathrm{W}$ Long), SE end of town of Brantford, Brant Co., Ontario, Canada. From base of Pit 2 within center of incompletely excavated longhouse structure. Coll. 1969 and subm. 1970 by W. C. Noble. Comment (W.C.N.): date helps establish history and development of longhouses and corn horticulture in SW Ontario. Cord-marked and incised pottery sherds of Porteous site fall transitionally between earlier Princess Point complex and later Glen Meyer branch of Early Ontario Iroquois tradition.

\section{I-4684. St. James Mound, Manitoba}

$220 \pm 90$

Wood from St. James mound $\left(49^{\circ} 53^{\prime} 45^{\prime \prime}\right.$ N Lat, $97^{\circ} 16^{\prime} 45^{\prime \prime} \mathrm{W}$ Long), St. James-Assiniboia, Manitoba, Canada. Part of pole near bottom of central burial pit. Coll. and subm. 1969 by R. J. Nash, Manitoba Mus. of Man and Nature, Winnipeg, Manitoba. Comment (R.J.N.): date agrees with artifactual ages and indicates mound building in Manitoba continued into early historic times.

\section{St. Mungo Cannery site series, Canada}

Charcoal from St. Mungo Cannery site, $S$ bank of $S$ arm of Fraser R., opposite New Westminster on Fraser Delta $\left(49^{\circ} 09^{\prime} 25^{\prime \prime} \mathrm{N}\right.$ Lat, $122^{\circ}$ $56^{\prime}$ 30" W Long), British Columbia, Canada. Coll. 1969 by G. Calvert, L. Calvert, S. Davidson, and R. Munro; subm. 1969 by G. Calvert, Vancouver Centennial Mus.

\section{I-4685. Dg Rr 2: C 5}

$3970 \pm 105$

Excavation Unit C 1, Level 14, in matrix of gray-brown earth, mussel, clam, and burnt shell. From $1.5 \mathrm{~m}$ below datum plane, $1.2 \mathrm{~m}$ below surface, assoc. with series of hearth structures in middle layers of site.

\section{I-4686. Dg Rr 2: C 10}

$390 \pm 95$

Excavation Unit C 1, Level 2, in matrix of dark soil, crushed shell, ash, and fire-cracked rock. From $37 \mathrm{~cm}$ below datum plane. Comment (G.C.): dates most recent layer of site.

\section{I-4687. Dg Rr 2: C 11}

$800 \pm 95$

Excavation Unit $\mathrm{C}$ 2, in matrix of red, hard-baked ash, Hearth Feature 2. From 62 to $64 \mathrm{~cm}$ below datum plane. Comment (G.G.): dates Marpole phase material.

I-4688. Dg Rr 2: C 17

Excavation Unit C 2, Level 27, in matrix of mussel, shell, clay, and 
gray-brown earth. From $2.1 \mathrm{~m}$ below Datum Plane A. Comment (G.C.): dates earliest level of site.

I-4869. Dg Rr 2: C 20

$1120 \pm 95$

A.D. 830

Excavation Unit D 2, Level 5A, in pit of red-brown sandy soil. From $79 \mathrm{~cm}$ below datum plane.

General Comment (G.C.): St. Mungo's is oldest shell midden site on Fraser Delta. Artifact assemblage suggests link between Eayem phase of Fraser Canyon and perhaps an early manifestation of Marpole phase of Fraser Delta (Calvert, ms. in preparation).

\section{Trout Lake series, Canada}

Charcoal from $\mathrm{N}$ shore of small lake ca. $1.6 \mathrm{~km} \mathrm{NE}$ of Trout Lake (68 $58^{\circ} \mathrm{N}$ Lat, $138^{\circ} 42^{\prime} \mathrm{W}$ Long), Arctic Yukon coast, Canada. Coll. and subm. 1968 to 1970 by B. C. Gordon, Archaeol. Dept., Univ. of Calgary, Alberta, and B. Yorga.

\section{I-3911. Eskimo housepit, Sample 1}

A.D. 1690

$260 \pm 90$

From hearth excavated in Eskimo housepit, Site NfVi-2, on SW sloping ridge. Comment (B.C.G.): date verifies estimate of late prehistoric Eskimo campsite. Assoc. artifacts: antler rakes, picks, ground slate knives and points, bone awls, etc.

\section{I-4447. 'Y' pit, Sample 1}

$4590 \pm 110$

Disseminated charcoal in soil from top of ' $\mathrm{Y}$ ' pit hearth. Assoc. with British Mountain artifacts. Lab. Comment: carbon content 1.9\%, no $\mathrm{NaOH}$ pretreatment.

\section{I-4985-A. ' 'Y' pit, Sample 2a}

$5380 \pm 125$ 3430 B.c.

Disseminated charcoal and willow twigs from intermediate and lower levels of large British Mountain hearth at NeVi-1.

\section{I-4985-B. ' $Y$ ' pit, Sample $2 \mathrm{~b}$}

$5490 \pm 125$

Samples I-4985 A and B were taken from homogenized sample concentration immediately below I- 4447 by flotation in double-distilled ion exchange water and subsequent rootlet removal.

General Comment (B.C.G.): pollen analysis and discovery of caribou bone and seven hearths in infilled natural bedrock depression substantiates belief that people bearing British Mountain tool kits were hunters frequenting Trout Lake region in autumn hunts.

\section{Africa}

I.4862. Leopard's Kopje Main Kraal

$$
1130 \pm 95
$$

A.D. 820

Charcoal from $24 \mathrm{~km} \mathrm{NE}$ of Bulawayo $\left(20^{\circ} 07^{\prime} \mathrm{S}\right.$ Lat, $28^{\circ} 26^{\prime}$

E Long), Rhodesia. From storage pit of the Zhizo phase of Rhodesian 
Iron age (Robinson, 1959; 1966). Coll. and subm. 1970 by T. N. Huffman, Natl. Mus. of Rhodesia, Bulawayo, Rhodesia. Comment (T.N.H.): dates end of Zhizo phase at site.

\section{E. Europe}

\section{Gibbins' Brook series, Stanford, Kent, England}

Sedge peat from valley bog at Stanford $\left(51^{\circ} 06^{\prime} 38^{\prime \prime} \mathrm{N}\right.$ Lat, $01^{\circ} 00^{\prime}$ 94" E Long), Kent, England. Coll. and subm. 1969 by A. Thorley, Dept. Geol. and Geog., Sir John Cass College, London.

\section{I-4513. Gibbins' Brook I}

$6260 \pm 125$

From 195 to $210 \mathrm{~cm}$ below surface. Peat cutting for fuel below this level.

\section{I-4514. Gibbins' Brook II}

$8070 \pm 200$

From $400 \mathrm{~cm}$ depth.

General Comment (A.T.): dates correlate with pollen evidence. Archaeol. evidence agrees with dates and suggests earlier human clearance of vegetation in SE England than in most parts of country.

\section{I-4542. Castle Hill, England}

$2505 \pm 100$

555 B.c.

Carbonized oak beam from multivallate Iron-age hill-fort, Castle Hill, $25 \mathrm{~km} \mathrm{~S}$ of Huddersfield (53 $40^{\prime} \mathrm{N}$ Lat, $01^{\circ} 46^{\prime} \mathrm{W}$ Long), Almondbury, Yorks, England. From uppermost of series of successive rampart structures (Varley, 1967). Coll. 1969 by Adrian Hovercroft and W. J. Varley; subm. 1969 by W. J. Varley for Rolson Mem. Mus., Ravensknowle, Huddersfield, Yorks. Comment (W.J.V.): date connects timberbraced hill fort rampart structures of Central England chronologically with Scottish series, particularly Dun Lagaidh.

\section{I-4234. Lough Derravaragh, Ireland}

$5360 \pm 110$

Charcoal from fen-peat deposit, Clonava Townland, Lough Derravaragh $\left(53^{\circ} 40^{\prime} \mathrm{N}\right.$ Lat, $07^{\circ} 22^{\prime} \mathrm{W}$ Long), Co. Westmeath, Ireland. Assoc. with chert implements, debitage of Larnian (Mesolithic) type and burned stone (R., 1961, v. 3, p. 32). Coll. 1968 and subm. 1969 by G. F. Mitchell, Univ. of Dublin, Dublin, Ireland. Comment (G.F.M.): Mesolithic type chert implements were found on several lake shores in Irish Midlands. At some sites they seem assoc. with Neolithic type polished stone axes. Clonava $\mathrm{Td}$. is the only site where they are in primary position stratified in fen-peat. Date corresponds with Newferry, Bann flakes (Mesolithic) and polished stone axes $5290 \pm 170$ (D-36) and Dalkey I. transition $5300 \pm 170$ (D-38).

$$
\text { F. Hawaii }
$$

\section{Makaha Valley series I, Oahu, Hawaii}

Charcoal from Lower Makaha Valley (21 ${ }^{\circ} 9^{\prime} \mathrm{N}$ Lat, $158^{\circ} 12^{\prime} 30^{\prime \prime}$ 
W Long), Oahu, Hawaii. From Archaeol. Zone 1. Subm. 1969 by R. C. Green (except as noted), Bernice P. Bishop Mus., Honolulu, Hawaii (Green, 1969; 1970).

I-4199. MVP Ca 36

From Site C4-17, Fireplace 3. Coll. 1969 by J. Takayama. Comment (R.C.G.): dates 1 of 2 pit or oven type fireplaces. Date is one of earliest for Makaha Valley (I-4201, this list).

\section{I-4200. MVP Ca 37}

$370 \pm 100$

From Site C4-17a, Fireplace 2. Coll. 1969 by J. Takayama. Comment (R.C.G.): date is one of earliest for perimeter fireplace assoc. with Cshaped field shelter (I-4121, this list). A later occupation of same shelter is dated by $\mathrm{I}-4306$, this list.

\section{I-4201. MVP Ca 38}

$720 \pm 105$

From Site C4-18a, Fireplace 2. Coll. 1969 by J. Takayama. Comment (R.G.G.): date is one of earliest for Makaha Valley and is from 1 of 2 pit or oven type fireplaces (I-4199, this list).

\section{I-4121. MVP Ca 2}

\section{A.D. 1580}

$370 \pm 90$

From Site C4-39, rectangular fireplace. Coll. 1969 by J. Takayama. Comment (R.C.G.): Sample I-4200 and this one from similar context, indicate time depth of 400 to $500 \mathrm{yr}$ for perimeter fireplaces and Cshaped shelters.

\section{I-4122. MVP Ca 7}

$$
270 \pm 90
$$

From Site C4-38, Fireplace 3. Coll. 1969 by J. Takayama. Comment (R.C.G.): sample stratigraphically earlier than existing C-shaped shelter at Site C4-38, and 1 of 3 dated samples from that site (see I-4311 and I-4310).

\section{I-4311. MVP Ca 54}

From Site C4-38, Fireplace 2. Coll. 1969 by J. Rasor. Comment (R.C.G.): sample probably assoc. with remnants of C-shaped shelter earlier than existing one at Site C4-38.

\section{I-4310. MVP Ca 53}

$$
230 \pm 95
$$

From Site C4-38, Fireplace 1. Coll. 1969 by J. Rasor. Comment (R.C.G.): sample dates existing C-shaped field shelter at C4-38. Dates suggest relatively short time for occupational sequence of site.

\section{I-4120. MVP Ca 1}

From Site C4-37, NW firepit in G-1. Coll. 1968 by K. Ishizuki. Comment (R.G.G.): sample from fireplace outside wall, and perhaps earlier than L-shaped shelter at C4-37. 
I-4306. MVP Ca 43

From Site C4-17a, Fireplace 1. Coll. 1969 by J. Takayama. Comment (R.C.G.): dates late occupation at C4-17a.

\section{I-4961. Storage Pit, MVP-63}

A.D. 1335

$615 \pm 140$

From $30 \mathrm{~cm}$ depth in small rock enclosure. Coll. 1970 by E. Ladd; subm. by Y. H. Sinoto. Comment (Y.H.S.): dates age of structure believed to be storage pit.

\section{Makaha Valley series II, Oahu, Hawaii}

Charcoal from Makaha Valley $\left(23^{\circ} 30^{\prime} \mathrm{N}\right.$ Lat, $158^{\circ} 11^{\prime} \mathrm{W}$ Long), Oahu, Hawaii (Green, 1969; 1970).

\section{I-4718. Kaneaki Heiau}

$380 \pm 120$

A.D. 1570

From temple $60 \mathrm{~cm}$ depth, Survey area 8, Lower Makaha Valley. Coll. 1969 by E. Ladd; subm. by Y. H. Sinoto, B. P. Bishop Mus., Honolulu, Hawaii. Comment (Y.H.S.): dates early limit of construction of heiau (temple).

\section{I-4823. Terrace, $60 \mathrm{~cm}$}

A.D. 1750

$$
200 \pm 95
$$

From walled agricultural terrace $60 \mathrm{~cm}$ depth, Survey area 17, Upper Makaha Valley. Coll. 1970 by P. Rosendahl and T. Riley; subm. by D. E. Yen. Comment (Y.H.S.): dates later of 2 strata believed to be "cultivation layers" in which wet-land taro was planted.

\section{I-4824. Terrace, 1.15 to $1.42 \mathrm{~m}$}

$445 \pm 95$

From walled agricultural terrace 1.15 to $1.42 \mathrm{~m}$ depth, Survey area 17, Upper Makaha Valley. Coll. 1970 by P. Rosendahl and T. Riley; subm. by D. E. Yen. Comment (Y.H.S.): dates earlier of 2 strata believed to be "cultivation layers" in which wet-land taro was grown.

\section{I-4825. Terrace, 37 to $93 \mathrm{~cm}$}

$565 \pm 110$

From behind wall of terrace 37 to $93 \mathrm{~cm}$ depth, Survey area 17, Upper Makaha Valley. Coll. 1970 by N. Carter; subm. by D. E. Yen. Comment (Y.H.S.): dates possible construction time of agricultural terrace wall.

I-4826. Terrace, 30 to $45 \mathrm{~cm}$

From below terraced platform 30 to $45 \mathrm{~cm}$ depth, Survey area 17, Upper Makaha Valley. Coll. 1970 by T. Riley and P. Rosendahl; subm. by D. E. Yen. Comment (Y.H.S.): dates structure after initial construction.

\section{I-4827. Terrace, 85 to $111 \mathrm{~cm}$}

$405 \pm 90$

From walled agricultural terrace 85 to $111 \mathrm{~cm}$ depth, Survey area 17, Upper Makaha Valley. Coll. and subm. 1970 by D. E. Yen. Com- 
ment (Y.H.S.): dates lower portion of stratum believed to be "cultivation layer" for wet-land taro.

\section{I-4926. Maui, Hawaiian Islands, Site MA-B11-2/3 A.D. 1655}

$295 \pm 90$

Hardwood housepost from Palauea $\left(20^{\circ} 40^{\prime} 30^{\prime \prime} \mathrm{N}\right.$ Lat, $156^{\circ} 26^{\prime}$ $30^{\prime \prime}$ W Long), Maui, Hawaiian Is. Housepost found in situ in stone wall house foundation. Coll. and subm. 1970 by P. V. Kirch, B. P. Bishop Mus., Honolulu, Hawaii. Comment (P.V.K.): dates main feature of small hamlet occupied by people with maritime economy (Kirch, 1970).

$$
\text { G. Mexico }
$$

\section{Becan, Campeche series, Mexico}

Charcoal mixed with gravel and plaster from Becan, Campeche (18 $30^{\prime} 36^{\prime \prime} \mathrm{N}$ Lat, 89 $28^{\prime} 24^{\prime \prime}$ W Long), Mexico. Samples securely sealed under floors of 2 rooms of Structure IV, a "Rio Bec" style construction. Coll. 1969 by P. Thomas and subm. 1969 by E. W. Andrews, Middle Am. Research Inst., Yucatan, Mexico.

I-4286. Becan, Campeche, 1

From top (last) floor, Rm. 9.

I-4287. Becan, Campeche, 2

From top floor, Rm. 8 .

General Comment: (E.W.A.): 1st dates in previously unexcavated part of Maya Lowlands. Helps date architectural construction, define chronologic position of pottery and artifacts sealed below floors and extensive midden deposits overlying floors.

\section{Tlapacoya series, Basin of Mexico}

Samples from Tlapacoya, once an island in Chalco Lake, Basin of Mexico (19 $19^{\circ} \mathrm{N}$ Lat, $98^{\circ}$ 55' W Long), Mexico. Subm. 1969 by J. L. Lorenzo, Inst. Nac. Antropol. e Historia, Moneda, Mexico.

\section{I-4406. Tlapacoya IV, Layer XIII}

$3310 \pm 110$

Peaty material mixed with pumice from Riparian zone in Tlapacoya (Niederberger, 1969). Coll. 1969 by C. Niederberger and J. Lorenzo. Comment (J.L.L.): dates base of Ceramic Formative occupation.

\section{I-4404. Tlapacoya IV, Layer XVII-A 28}

$4250 \pm 110$

Charcoal from $2.57 \mathrm{~m}$ depth preceramic horizon termed Zohapilco II. Coll. 1969 by C. Niederberger and J. Lorenzo.

\section{I-4405. Tlapacoya IV, Layer XXIII bis-A 17}

$7040 \pm 115$ pilco I. Coll. 1969 by C. Niederberger and J. Lorenzo. 
I-4449. Tlapacoya I, Alfa 2

Charcoal from Hearth III on Pleistocene beach of Chalco Lake, assoc. with animal bones with no anatomic relation and lithic industry. Coll. 1969 by Raul Arana. Comment (J.L.L.): date clusters with A-790A (22,400 B.P., R., 1971, v. 13, p. 15; and GX-0959, 23,150 B.P.) from same area.

\section{H. Australia}

\section{Puntutjarpa Rock-shelter series, Australia}

Charcoal and ash samples from Puntutjarpa Rock shelter, $4.8 \mathrm{~km}$ $\mathrm{S}$ of Warburton Ranges Mission (26 $6^{\circ} \mathrm{S}$ Lat, $127^{\circ} \mathrm{E}$ Long), Western Australia. Coll. 1967 and subm. 1970 by R. A. Gould, Dept. Anthropol., American Mus. Nat. History, New York, N.Y. (Gould, 1968).

\section{I-5319. Trench 2, Square 14}

$10,170 \pm 230$

8220 B.C.

From well-defined hearth directly above cave floor, 117 to $122 \mathrm{~cm}$ below ground surface. Comment (R.A.G.): earliest radiocarbon date for cultural materials in $\mathrm{W}$ desert of Australia, assoc. with earliest human occupation of Puntutjarpa Rock shelter. Assoc. materials include remains of modern desert fauna, horsehoof cores, large flake scrapers, and small-hafted micro-adzes. The micro-adzes are earliest examples of smallhafted stone tools discovered in Australia.

\section{I-5320. Trench 2, Square 11}

$435 \pm 90$

Combined sample from 2 nearby hearths, 43 to $48 \mathrm{~cm}$ below ground surface. Comment (R.A.G.): the 2 hearths represent limits of an excavated campsite. Assoc. artifacts included surral-backed blades and a large horsehoof core.

\section{I-5321. Trench 3, Square 49}

$3840 \pm 105$

From large hearth 28 to $38 \mathrm{~cm}$ below ground surface. Comment (R.A.G.): furnishes final date for a presumed well, used to secure drinking water from localized water table within $\mathrm{W}$ cave.

\section{I-5475. Trench 2, Square 11}

$6710 \pm 125$

4760 в.c.

From $78 \mathrm{~cm}$ below ground surface. Comment (R.A.G.): sample checks dates of same level from nearby Trench I (I-3387 and I-3388, R., 1969, v. 11, p. 87).

\section{I-5476. Trench 2, Square 46}

$4010 \pm 105$

From well-defined hearth, 105 to $112 \mathrm{~cm}$ below ground surface. Comment (R.A.G.): sample stratigraphically above I-5475, assoc. with earliest appearance of well-made backed blades. 
I-5318. Winpuly (Winburn Rocks) site, Australia

Charcoal from Winburn Rocks, $107 \mathrm{~km}$ E of Warburton Ranges Mission (26 ${ }^{\circ} \mathrm{S}$ Lat, $127^{\circ} \mathrm{E}$ Long), Western Australia. From well-defined hearth in Tr. 1, Sq. 7, 15 to $31 \mathrm{~cm}$ below ground surface. Coll. and subm. 1970 by R. A. Gould. Comment (R.A.G.): site is shallow remnant of extensive open air camp. Stone artifacts closely resemble those from upper levels of Puntutjarpa (Gould, 1968).

\section{I-5477. Nyawar (Ranford Hill site), Australia}

Charcoal from Ranford Hill, 72

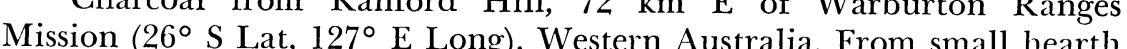
inside $\mathrm{E}$ rock shelter, 76 to $92 \mathrm{~cm}$ below ground surface and scrapers assoc. with hearth; a single-backed blade stratigraphically above hearth. Coll. and subm. 1970 by R. A. Gould.

\section{Chansen series, Thailand}

\section{Asia}

Main occupation of Chansen (15 $07^{\prime} \mathrm{N}$ Lat, $100^{\circ} 27^{\prime} \mathrm{E}$ Long), Takli Dist., Nakhon Sawan Prov., Thailand, belongs to Dvaravati period (ca. 6th to 10th century A.D.), earliest historic period of Thailand. Coll. and subm. 1969 by G. F. Dales, Univ. Mus., Univ. of Pennsylvania, Philadelphia. Samples supplement 1968 series of Univ. of Pennsylvania (R., 1970, v. 12, p. 587). Dates cited were calculated by the Univ. of Pennsylvania lab. from Isotopes' raw data using 5568 yr half-life.

\section{I-4368. Phase IV Late Funan}

$1416 \pm 84$

Charcoal, Sample 69-2, from Operation Dg, Lot 16, St. $16,100 \mathrm{~cm}$ beneath surface. Mixed with shells, rootlets, and limestone fragments. Comment (G.F.D.): only Phase IV sample, agrees with traditional historic dating of this pre-Dvaravati phase.

\section{I-4369. Phase V or early VI, Late Dvaravati}

\section{A.D. 1002}

$948 \pm 78$

Charcoal, Sample 69-3, bamboo or reed, some matting, from Operation Eb, Lot 7, St. 3, 48 to $50 \mathrm{~cm}$ beneath ground surface. Comment (G.F.D.): assoc. pottery sherds resemble material from late Dvaravati sites in central Thailand.

\section{I-4370. Phase II, Pre-Funan}

$1644 \pm 85$

Charcoal, Sample 69-10, of hardwood and bamboo, Operation Dg, Lot 43, Pit 1, $230 \mathrm{~cm}$ below ground level. Comment (G.F.D.): from good context that dates end of pre-Funan Indianized cultural phase. 


\section{REFERENCES}

Ballagh, T. M. and Runge, E. C. A., 1970, Clay-rich horizons over limestone, illuvial or residual: Soil Sci. America Proc., v. 34, p. 534-536.

Bartelli, L. J. and Odell, R. T., 1960, Field studies of clay-enriched horizons of some pedzolic soils in Illinois: Soil Sci. Soc. Amer. Proc., v. 24, p. 388-390.

Black, R. F. 1969, Valderan glaciation in western upper Michigan: 12th Conf. Internatl. Assoc. Great Lakes Res. Proc., p. 116-123.

Bretz, J. H., 1953, Glacial Grand River, Michigan: Michigan Acad. Sci. Papers, v. 38, p. $359-382$.

Buckley, J. D., Trautman, M. A., and Willis, E. H., 1968, Isotopes' radiocarbon dates VI: Radiocarbon, v. 10, p. 246-294.

Buckley, J. D. and Willis, E. H., 1969, Isotopes' radiocarbon dates VII: Radiocarbon, v. 11, p. 53-105. 129 .

Eschman, D. F. and Farrand, W. R., 1970, Glacial history of the Glacial Grand Valley: Michigan Basin Geol. Soc., Guidebook for Field Trips, p. 131-157.

Farrand, W. R., 1969, The Quaternary history of Lake Superior: 12th Conf. Internatl. Assoc. Great Lakes Res. Proc., p. 181-197.

Funk, R. E., et al., 1969b, The archeology of Dutchess Quarry Cave, Orange County, New York: Pennsylvania Archaeol., v. 39, no. 1-4, p. 7-22.

Funk, R. E., Fisher, D. W., and Reilly, E. M., Jr., 1970, Caribou and paleoindian in New York State: a presumed association: Am. Jour. Sci., v. 268, p. 181-186.

Funk, R. E., Walters, G. R., and Ehlers, W. F., 1969a, A radiocarbon date for early man from Dutchess Quarry Cave: New York State Archeol. Assoc. Bull., no. 46, p. 19-21.

Godwin, H. and Willis, E. H., 1962, Cambridge University natural radiocarbon measurements V: Radiocarbon, v. 4, p. 57-70.

Godwin, H., Willis, E. H., and Switsur, V. R., 1965, Cambridge University natural radiocarbon measurements VII: Radiocarbon, v. 7, p. 205-212.

Gould, R. A., 1968, Preliminary report on excavations at Puntutjarpa Rock-shelter near Warburton Ranges, Western Australia: Archaeol. and Physical Anthropol. in Oceania, v. 3, no. 3, p. 161-185.

Green, R. C., 1969, Makaha Valley hist. proj. interim rept. No. 1, Pacific anthropol. recs. no. 4: Bernice P. Bishop Mus., Honolulu, Hawaii.

- 1970, Makaha Valley hist. proj. interim rept. no. 2, Pacific anthropol. recs. no. 10: Bernice P. Bishop Mus., Honolulu, Hawaii.

Grosscup, G. L., 1960, The cultural history of Lovelock Cave, Nevada: Univ. of California Archaeol. Survey Repts., no. 52, Berkeley.

Gruhn, K., 1961, The archaeology of Wilson Butte Cave, S. central Idaho: Idaho State Coll. Mus. Occas. Papers, no. 6, Pocatello.

Guilday, J. E., 1968a, Archaeological evidence of caribou from New York and Massachusetts: Jour. Mammalogy, v. 49, no. 2, p. 344-345.

1968b, Grizzly bears from eastern North America: Am. Midland Naturalist, v. 79 , no. 1 , p. $247-250$.

1969, A possible caribou-paleo-indian association from Dutchess Quarry Cave, Orange County, New York: New York State Archaeol. Assoc. Bull. 45, p. 24 -

29.
Judson, S., 1963, Erosion and deposition of Italian stream valleys during historic time: Science, v. 140, p. 898-899.

Kaye, C. A. and Barghoorn, Esa, 1964, Late Quaternary sea-level change and crustal rise at Boston, Massachusetts, with notes on the autocompaction of peat: Geol. Soc. America Bull., v. 75, no. 2, p. 63-80.

Kirch, P. V., 1970, Archaeology in the Ahupua's of Palauea, Southeast Maui: Pacific Anthropol. Recs., Bernice P. Bishop Mus., p. 1-32.

Lawn, Barbara, 1970, Univ. of Pennsylvania Dates XIII: Radiocarbon, v. 12, p. 587.

Leverett, F., 1929, Moraines and shore lines of the Lake Superior region: U. S. Geol. Survey, Prof. Paper 154, p. 1-72.

Leverett, F. and Taylor, F. B., 1915, The Pleistocene of Indiana and Michigan and the history of the Great Lakes: U. S. Geol. Survey, Mon. 53, p. 1-529.

Loud, L. L. and Harrington, M. R., 1929, Lovelock Cave: Univ. of California Pubs. in Am. Archaeol. and Ethnol., v. 25, no. 1, Berkeley.

Marsters, B., Spiker, E., and Rubin, M., 1969, U. S. Geological Survey radiocarbon dates X: Radiocarbon, v. 11, p. 212. 
McAulay, I. R. and Watts, W. A., 1961, Dublin radiocarbon dates I: Radiocarbon, v. 3, p. $26-38$

Napton, L. K., 1969, Archaeological and paleobiological investigations in Lovelock Cave, Nevada: Kroeber Anthropol. Soc. Spec. Pub., no. 2, Berkeley.

Niederberger, C., 1969, Paleocologia humana y playas lacustres post-pleistocenicas en Tlapacoya, Edo. de Mexico: I.N.A.H. Bol., no. 37, Mexico.

Ogden, J. G., III, and Hay, R. J., 1967, Ohio Wesleyan University natural radiocarbon measurements III: Radiocarbon, v. 9, p. 319.

Olsen, S. J., 1959, Fossil mammals of Florida: Florida Geol. Survey Spec. Pub., no. 6 p. $1-44$.

Prest, V. K., 1969, Retreat of Wisconsin and recent ice in North America: Geol. Survey of Canada, 1 sheet.

Raemsch, B. E., 1970, Preliminary report on the Adequentaga site: Yager Mus. Pubs. Anthropol. Bull. no. 2.

Redfield, A. C., 1965, Ontogeny of a salt marsh estuary: Science, v. 147, p. 50-55.

Redfield, A. C. and Rubin, Meyer, 1962, The age of salt marsh peat and its relation to recent changes in sea level at Barnstable, Massachusetts: Natl. Acad. Sci. Proc., v. 48 , p. $1728-1735$.

Ritchie, W. A., 1945, An early site in Cayuga County, New York: Research Recs. Rochester Mus. Arts and Sci., no. 7, p. 1-22. 163-177.

Robinson, K. R., 1959, Khami Ruins: Cambridge, Cambridge Univ. Press. 1966, The Leopard's Kopje culture, its position in the Iron age of Rhodesia: S. African Archaeol. Bull., no. 21, p. 81

Rubin, M. and Suess, H. E., 1956, U. S. Geological Survey radiocarbon dates III: Science, v. 123 , p. $442-448$.

Russell, I. C. and Leverett, Frank, 1908, Description of the Ann Arbor quadrangle, Mich.: U.S.G.S. G. Atlas Ann Arbor Fol. 155, p. 1-15.

Schoewe, W. H., 1924, The origin and history of extinct Lake Calvin: Iowa Geol. Survey, v. 29 , p. $49-222$.

Sharpenseel, H. W., Pietig, F., and Tamers, M. A., 1968, Bonn radiocarbon measurements I: Radiocarbon, v. 10, p. 8-28.

Skeels, M. A., 1962, The Mastodons and Mammoths of Michigan: Mich. Acad. Papers, v. 47, p. $101-133$.

Smith, I. F., III, 1968, News-William Penn Memorial Museum: Carnegie Mus. Archaeol. Newsletter, no. 41, p. 7.

Van Dyke, S., 1969, Report on the excavations at SMa-100: Traganza Anthropol. Mus., San Francisco State College.

Varley, W. J., 1967, Castle Hill, Almondbury, a brief guide to the excavations thereof 1939 to 1969: Folson Mem. Mus., Huddersfield, Yorks.

Vita-Finzi, C., 1966, The new Elysian fields: Am. Jour. Archaeol., v. 70, p. 175-178. 1969, The Mediterranean Valleys: Cambridge, Cambridge Univ. Press.

Warren, C. N., 1968, The view from Wenas: a study in plateau prehistory: Idaho State Coll. Mus. Occas. Papers, no. 24.

Washbourn, C. K., 1967, Lake levels in Quaternary climates in the eastern Rift Valley of Kenya: Nature, v. 216, p. 672-673.

Washbourn, C. K. and Kamau, , 1970, Lake Quaternary chronology of the Nakuru Elmenteita basin, Kenya: Nature, v. 226, p. 253-254.

Wilson, R. L., 1967, The Pleistocene Vertebrates of Michigan: Mich. Acad. Papers, v. 52 , p. $197-234$.

Woodworth, J. B. and Wigglesworth, E., 1934, Geography and geology of the region including Cape Cod, etc.: Harvard College Mus. Comp. Zool. Mem., v. 52, 338 p.

Zumberge, J. H. and Benninghoff, W. S., 1969, A Mid-Wisconsin peat in Michigan, U.S.A.: Pollen et Spores, v. 11, p. 585-601. 